УДК 821.161. 2-1.09.1

Л. М. Семененко

\title{
КОНЦЕПТ КОХАННЯ В ЛІРИЧНИХ ТВОРАХ ОЛЕКСАНДРА ОЛЕСЯ
}

Семененко Л. М. Концепт кохання в ліричних творах Олександра Олеся.

У статті розглядається специфіка творчого доробку одного з провідних поетів української літератури кінця XIX - початку XX століть Олександра Олеся (Кандиби). Автор визначає провідні особливості змісту та художньої реалізації концепту кохання в ліричних поезіях митця. Основна увага приділена аналізу постаті ліричного героя та збірного образу жінки. засіб.

Ключові слова: літературна традиція, модернізм, ліричний герой, виражальний

Семененко Л. Н. Концепт любви в лирических произведениях Александра Олеся.

В статье рассматривается специфика творчества одного из ведущих поэтов украинской литературы конца XIX - начала XX веков Александра Олеся (Кандыбы). Автор определяет ведущие особенности содержания и художественной реализации концепта любви в лирических стихах художника слова. Основное внимание уделено -345- ○ л. М. Семененко, 2015. 
анализу фигуры лирического героя и собирательного образа женщины.

Ключевые слова: литературная традиция, модернизм, лирический герой, выразительное средство.

Semenenko L. M. Concept of love in lyrical works Oleksandr Oles.

In the article the specificity of creative works of one of the leading poets of Ukrainian literature late XIX - early XX centuries Alexander Oles (Kandyba). The author identifies the leading features of artistic content and implementation of the concept of love in lyrical poetry artist. The main focus is on analyzing figures lyrical and collective image of women.

Keywords: literary tradition, modernism, lyrical hero, artistic means.

Олександр Олесь увійшов як поет в українську літературу на межі XIX та XX століть, у переламний час, коли поглиблювався конфлікт між старими традиціями і новими тенденціями i в історичному бутті, i в літературному процесі. У літературі ця епоха характеризується унікальністю співіснування різноманітних поетичних напрямків та стилів, синкретизмом елементів різних художніх концепцій та практик. Окремі автори або поєднували риси цих напрямків, або вели активні пошуки новаторських підходів до літератури, у центрі яких так чи так перебувала людина. Творчість Олександра Олеся стала етапною для української поезії своєї доби, оскільки відбивала складні перипетії конфлікту та взаємодії народницької та модерністської тенденцій. Високу художню й естетичну цінність творчості митця та актуальність для неї інтимних мотивів, зокрема, мотиву кохання, відзначали літературні критики різного час та спрямування: М. Гнатюк [1], Л. Голомб [2], М. Грушевський [3], О. Денисюк [4], С. Сфремов [5], М. Зеров [6], М. Неврлий [8], С. Павличко [10], І. Чернова [11]. Зокрема, М. Грушевський, указуючи на особливості розкриття інтимних мотивів у ліриці автора, зазначав: «У поезії серця, що нерозлучно спливається 3 поезією природи і займає таке велике місце в перших збірках Олеся, він являється магістром півтонів. Сердечні відчування лежать в одній площині 3 відчуваннями природи. В них дуже мало еротизму, дуже рідко виступає пожадливе почуття, зовсім чуже задоволене міркування...» [3, с. 258]. Відомий дослідник творчості поета М. Неврлий розкривав сутність «людського й мистецького феномена Олеся», вважаючи, що його винятковість полягає в «глибоко оригінальному поєднанні загальнолюдського 3 національним, в легкому, мелодійному, високо артистичному характері його поезій. В одному з його романсів традиційний український соловейко, оспівуваний Шевченком та іншими українськими поетами, закликає милувати й цілувати кохану, бо ж, мовляв, «знов молодість не буде». Вселюдське саrpe diem в українській одежі» [8, с. 11]. $Є$ й інші думки: С. Павличко наголошувала, ніби поетові бракувало слів, що (с) Л. М. Семененко, 2015. 
він виробив певні кліше, які переходять із вірша у вірш, його лірика «ще не вміла по-справжньому говорити про любов, тому вона непереконлива, декларативна» [10, с. 97]. Однак, актуальність концепту кохання для поетичного доробку поета бачиться безсумнівною.

Метою статті постає розкриття сутності, змісту та художньої реалізації концепту кохання в ліричних поезіях Олександра Олеся.

Як значущі в контексті аналізу осмислюємо образи ліричного героя та образ коханої. Саме ці образи утворюють специфічне семантичне поле, в межах якого функціонують ліричні почуття. Завдяки особливостям їх художнього втілення створюється певний настрій, символізуються культурософські цінності доби, як традиційні, так і модерністські. Розкриття концепту кохання у ліриці Олександра Олеся реалізується через створення складної та неоднозначної взаємодії відповідної парадигми ліричного героя та збірного жіночого образу.

Основним засобом передачі почуттів закоханих у творах Олександра Олеся українського періоду творчості $є$ традиційне для українського поетичного дискурсу співвіднесення почуттів та переживань людини із станами природи. Образи природи використовуються поетом для передачі найрізноманітніших перебігів внутрішнього буття ліричного героя, що характеризується підвищеною емоційністю. Усі події та явища навколишнього та внутрішнього світу викликають у нього суб'єктивні переживання, що виявляються у різного роду рефлексіях. Важливим є те, що відтворення почуттів через природу коливається в межах від фольклорної до індивідуально-авторської образності: Коли весні зрадіє світ увесь I заблищить в щасливій долі, I ти одна, в квітках $і$ травах, в полі десь, Серед весни, краси і волі Не зможеш більше серия зупинить, Що в грудях буде битись, мов шалене, I скрикнеш, - знай, не долетить Уже твій скрик тоді до мене... [9, с. 57].

Функціональне навантаження образів природи тісно пов'язується 3 перебігом як самого почуття, так i психічних станів закоханої особистості. Прийом психологічного паралелізму використовується автором для поетизації постаті коханої, що підсилюється персоніфікацією сил природи: $O$, не дивуйсь, що скільки зір на небі, Що ночі так прозора срібна мла, - Ця ніч ясна убралася для тебе, Для тебе й срібло розлила [9, с. 64]; Стоять вишні і журяться похилі, Що в хмари сонечко зайшло, Що листя й квіти облетіли... [9, с. 71].

Постать коханої жінки часто порівнюється поетом із різноманітними явищами та образами природи. Домінантними у цьому аспекті постають традиційні порівняння жіночої вроди із квітами. Образ 
коханої асоціюється поетом із «ніжним проліском», уста - 3 трояндами, чари - із в'юнком, руки - 3 лілеями. Змальовуючи образ жінки, автор використовує ряд пестливих слів: «красавице», «люба», «зоре», «душа моя», «кохана», «моє щастя», «моя пташко», що виявляють ліричні почуття. Настрої, пов'язані з жіночим образом, послідовно означаються як «хмари», «вечір», «похмурий день», «смеркання» тощо. У поезіях підкреслюються різні особливості жіночої вроди, при цьому переважно вживаються порівняння, метафори та епітети: Твої очі - ніжні квіти, $\mathrm{Ha}$ яких спинились сльози Після мук за світ безщасний, Як росинки після ночі [9, с. 91]; Ти в ліжку ще. На крилах золотих Тебе ще сон ясний колише I носе десь в просторах світових, В країнах див, утіх і тиші [9, с. 91].

Одним із виявів взаємодії чоловічого й жіночого начал у ліриці автора бачиться розкриття мотиву зради як утілення не лише чуттєвої опозиції він / вона, але й філософської опозиції людина / світ. Атрибутом буття зрадженого й покинутого закоханого стає самотність. Характерно, що зрадницею в поезіях Олександра Олеся постає саме жінка, яка здатна вбити не тільки любов, але й усе те, чим живе ліричний герой: Tu в my ніч другим зоріла, Ти другим вінок плела, Надо мною ж насміхалась I знущалась, як могла [9, с. 158]; Мене невірна розлюбила, I я блукаю сам не свій, Немов я кинутий остався Один в пустелі світовій [9, с. 128].

Сталим засобом художнього втілення концепту кохання в поетичному доробку Олександра Олеся постають риторичні питання, адресовані коханій жінці. Тематика таких питань достатньо різноманітна, однак основними $\epsilon$ ті, на які не знаходить відповіді ліричний герой: $T u$ зовсім мене не кохала, А я був повинен забуть... Чого ж ти так тяжко зітхала В той час, як збирався я в путь?.. Чого твої руки тремтіли, Чого ти тремтіла уся?! I роки уже пролетіли, А й досі не знаю ще я [9, с. 85]. Або в іншому вірші: Чому з тобою ми не хвилі? Удвох за руки б ми взялись I в край щзасливий полетіли, Де ждала нас любов колись [9, с. 87].

У творах еміграційного періоду поет, незважаючи на загострене відчуття відірваності від рідного краю й підкресленого трагізму, продовжує звертатися до почуття кохання, сподіваючись, що прийде нова любов, а 3 нею з'явиться й нова наснага до життя. Поет розглядає нові грані аналізованого концепту, з одного боку реалізуючи почуття більш стримано, а з іншого - відверто радіючи його появі: I знов любов, $i$ знов пісні, І крики дикі, голосні [9, с. 706].

Значний ряд віршів цього часу («Забуду все, лишу твої уста...», «Цілую вас в прекрасну вашу руку...», «3 тобою жити на одній землі...» та ін.) виявляє певну парадигму образу ліричного героя. Він бачиться вже в (с) Л. М. Семененко, 2015. 
інших обставинах, 3 іншим осмисленням любові, збагаченим життєвим досвідом. Водночас, пробудження і тривання інтимних почуттів високо цінується автором та його героєм, про що свідчить, зокрема, вірш «Так, я впевнивсь! Я люблю!..», пройнятий оптимістичним настроєм. Основним мотивом поезії постає радість від того, що знайдено справжнє кохання: Так, я впевнивсь! Я люблю! I люблю ї̈ без краю! А за щэо - $i$ сам не знаю. Знаю тільки, щңо люблю [9, с. 702]. Закоханого чоловіка любов робить сміливим, здатним на рішучі вчинки, самодостатнім, що теж тотожне літературній традиції: Раз я впевнивсь, щзо люблю, Не боюсь лихої слави! [9, с. 703].

Одним із модерністських виявів мотиву кохання в поезії Олександра Олеся є прагнення оцінювати його як найвище щастя буття, а його прихід асоціювати із космогонічними образами, що підкреслює неосяжність самого почуття: Любов, як сонце. Вона розцвітає, як вогняна Квітка на темному небі душі... [9, с. 676].

Специфічними для розкриття почуття кохання й закоханості в ліриці Олександра Олеся еміграційного періоду постають так звані «кав’ярняні» мотиви (М. Неврлий). Ці мотиви реалізуються через перебіг різноманітних ракурсів і вражень: зустріч у кав'ярні із незнайомкою («Сьогодні стрінемось...»), захоплення жіночою вродою («Вона приходе завжди в певний час...»), враження від спільних переживань («В кафе, наповненім юрбою...») та ін.. Важливим чинником демонстрації почуттів ліричного героя постає його сповідь, зізнання, адресовані предмету кохання: Мені було так дивно тепло з вами, Я вам про це ніколи не казав... Хіба б я висловив словами Все те, що серцем відчував [9, с. 667].

Для розкриття інтимних почуттів автор вдається до різноманітних виражальних засобів, провідними з яких є епітети, метафори, порівняння, риторичні запитання та різного роду паралелізми. Організуючим чинником художнього втілення концепту кохання постає образ ліричного героя, перебіг його станів, настроїв та почуттів, що детально фіксуються автором.

Більшість картин світу, пов'язаних зі сферою любові, подано в ліриці Олександра Олеся 3 позицій сприйняття та осмислення ліричного героя. Розгортання його парадигми в ракурсі інтимних почуттів відбувається через поступове наближення до межової ситуації, що дозволяє проникнути до самих основ буття, таємниць життя й смерті, минущого та вічного пошуку самого себе, гармонії зі світом. Характеризуючи образ ліричного героя в ракурсі інтимних почуттів, помічаємо, що герой ліричних поезій автора постає як виразно збірний образ, який перебуває в постійному пошуку, переживає складну гаму почуттів. Олександр Олесь уникає статичності постаті ліричного героя, а звертається до динамічного перебігу його 
почуттів, що виявляє певну еволюцію характеру протягом обох періодів творчості автора. Еволюція відбувається не лише у розкритті ставлення ліричного героя до людини та світу, але передусім у переживанні почуттів, пов'язаних із коханням, виразі цих почуттів, рисах поетизації образу коханої.

\section{Література}

1. Гнатюк Н. Дещо з життя Олександра Олеся / Н. Гнатюк // Всесвіт. - 1989. №2. - С. 145-146.

2. Голомб Л. Антеїзм лірики Олександра Олеся / Л. Голомб // Література. Фольклор. Проблеми поетики : зб. наук. праць. - Вип. 24. - Ч. 2. - К. : Акцент, 2006. C. 22-35.

3. Грушевський М. Поезія Олександра Олеся / М. Грушевський / Українське слово. Хрестоматія української літератури і критики ХХ ст. : у 4-х кн. - Кн. 1. - К. : Рось, 1994. - С. 257-265.

4. Денисюк О. Невідомі матеріали із спадщини Олександра Олеся / О. Денисюк / Укр. літературознавство : Респ. міжвід. науковий зб. - Вип. 55. - Львів, 1990. - С. 139-142.

5. Єфремов С. На початку нового віку : Олесь / С.Єфремов. - Історія українського письменства. - К. : Femina, 1995. - 283 с.

6. Зеров М. Від Куліша до Винниченка : Поезія Олеся і спроба нового іiі трактування / М. Зеров. - Твори : у 2-х т. - К. : Дніпро, 1990. - Т. 1. - С. 148-234.

7. Камінчук О. Неоромантик, символіст чи романтик? Естетичні тенденції творчості Олександра Олеся / О. Камінчук // Дивослово. - 2004. - № 12. - С. 46-49.

8. Неврлий М. Олександр Олесь. Життя і творчість / М. Неврлий. - К. : Дніпро, 1994. - $173 \mathrm{c}$.

9. Олесь О. Твори : у 2-х т. / О. Олесь. - Т. 1. - К. : Дніпро, 1990. - 880 с.

10. Павличко С. Дискурс модернізму в українській літературі / С. Павличко. - К. : Либідь, 1999. - 480 с.

11. Чернова І. Міфологема долі в художньому світі Олександра Олеся / І. Чернова // Слово і час. - 1998. - № 12. - С. 45-50.

Стаття надійшла до редакиії 21.07.2015 p. 